\title{
THE POLYTYPIC GENUS CELOTES \\ (LEPIDOPTERA: HESPERIIDAE: PYRGINAE) FROM THE SOUTHWESTERN UNITED STATES AND NORTHERN MEXICO*
}

\author{
By John M. Burns \\ Museum of Comparative Zoology, Harvard University
}

Although most species of American hesperiids are hard to determine, some are not; and none is more immediately distinct than the "streaky skipper," Celotes nessus (Edwards). Ever since it was described (in genus Pholisora) in I877, nothing else like it has been known. Indeed, since the turn of the century - despite abortive attempts of various workers to jam it into polytypic genera (such as Pyrgus [then commonly called Hesperia], Systasea, and Antigonus) - it has properly stood alone in the monotypic genus Celotes (Godman and Salvin I899). I feel, therefore, a measure of remorse in now describing a second species of Celotes that closely resembles the first.

Although I have accumulated data on Celotes since New Year's Eve of 196I, when I first recognized it as polytypic, I still see no clear clues to the evolutionary differentiation of $C$. nessus and the species to be described: they overlap fully in space and in time, and at least partly in choice of larval foodplants. The new species is a multivoltine mallow-eater occurring in a montane strip that runs northwest-southeast through the middle of the range of $C$. nessus.

Because $C$. nessus is both peculiar and familiar, the following description is comparative. And because original descriptions can be too tedious for words, this one is largely visual.

In preparing it, I have examined the genitalia of all specimens of Celotes available to me and possessed of an abdomen - a total of 529 individuals, of which 97 represent the new species. Wherever possible, I have also examined the metathoracic pouch of males. Each pinned specimen studied has received a sex-and-determination label.

The new specific name is a noun in apposition.

Celotes limpia new species

Holotype. - $\sigma^{\pi}$, Limpia Canyon, 5000 feet, Davis Mountains, 4 miles WNW of Fort Davis, Jeff Davis County, Texas, May 2,

\footnotetext{
*Manuscript received by the editor March 1, 1974.
} 
I959 (J. M. and S. N. Burns) [Museum of Comparative Zoology no. 31888].

Size. - On average, limpia is larger than nessus; and, in both species, females are larger than males, although size varies considerably (table I). In nessus, the wingspread of Texas specimens exceeds that of Arizona specimens by at least $\mathrm{I} \mathrm{mm}$.

Table 1. Maximum wingspread in well-mounted specimens of Celotes from Texas.

\begin{tabular}{|c|c|c|c|c|}
\hline Species & Sex & $\begin{array}{l}\text { Number } \\
\text { measured }\end{array}$ & $\begin{array}{l}\text { Win } \\
\text { Mean }\end{array}$ & $\begin{array}{l}(\mathrm{mm}) \\
\quad \text { Range }\end{array}$ \\
\hline nessus & $\hat{o}$ & 35 & 23.7 & $22-26$ \\
\hline$"$ & 우 & 22 & 25.1 & $23-27$ \\
\hline limpia & $\hat{o}$ & 39 & 25.9 & $23-29$ \\
\hline$"$ & $q$ & 24 & 27.8 & $25-31$ \\
\hline
\end{tabular}

Facies. - Fig. IE-H. Very like nessus (fig. I A-D), but with slightly larger and more conspicuous hyaline spots and a generally paler aspect.

Noteworthy in the latter connection is a set of pale areas between dark marks on the proximal $60 \%$ of the ventral secondary (i.e. from the three hyaline spots of the secondary inward): these pale areas are enlarged and whitened in limpia and hence usually more pronounced than in nessus. In dorsal view, unworn (particularly reared) specimens of limpia may show considerable grayish overscaling on the body and adjacent wing bases. The usually paler shades of brown and tan in limpia tend to make it reflect more and appear colder and harder and sometimes more contrasty. All of these average differences involving color are perceptible chiefly when limpia is compared with nessus from Texas; nessus from Arizona (where limpia does not occur) often essentially duplicates the facies of limpia - except insofar as the remarkably small average size of Arizona nessus gives its pattern a special sharpness. Wear and fading

Data for specimens in Fig. 1:

A, B - Sitting Bull Falls, 4650 feet, Guadalupe Mountains, Eddy County, New Mexico, V-26-1959 (J. M. and S. N. Burns).

C, D - Topotype. San Antonio, Bexar County, Texas, VI-30-1963 (J. M. Burns).

E, F - Holotype. Limpia Canyon, 5000 feet, Davis Mountains, 4 mi. WNW of Fort Davis, Jeff Davis County, Texas, V-2-1959 (J. M. and S. N. Burns).

G, H - Allotype. As for holotype, except V-1-1959. 


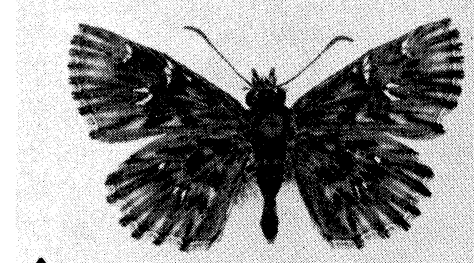

A
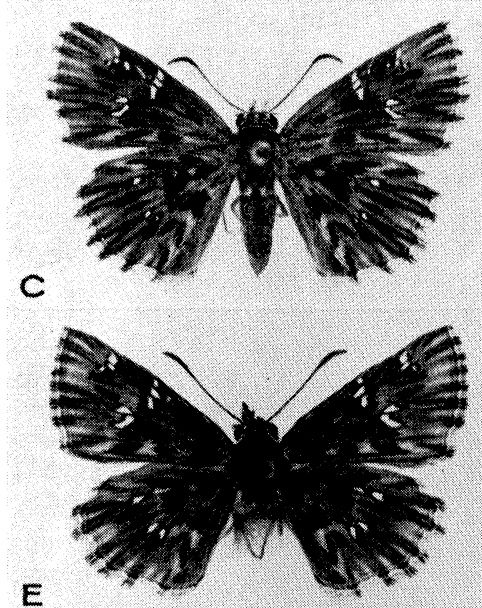

E

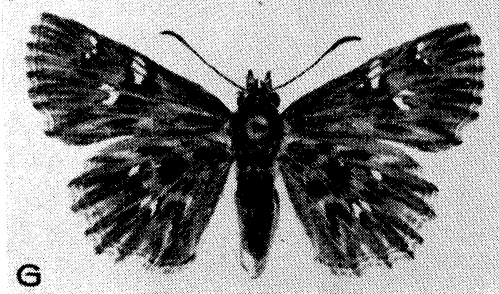

B

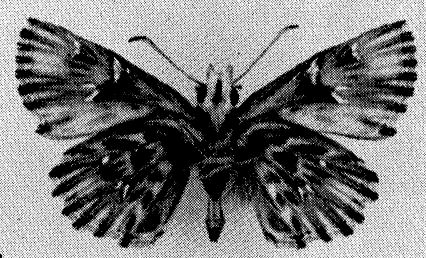

D

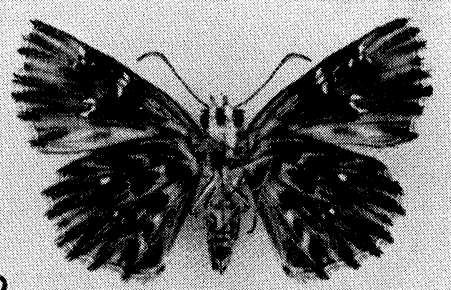

F

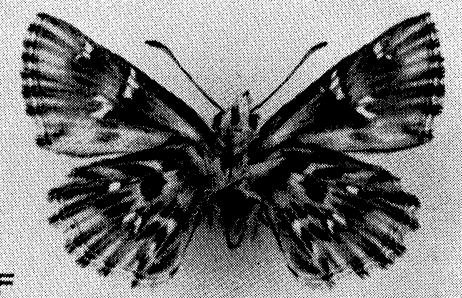

H

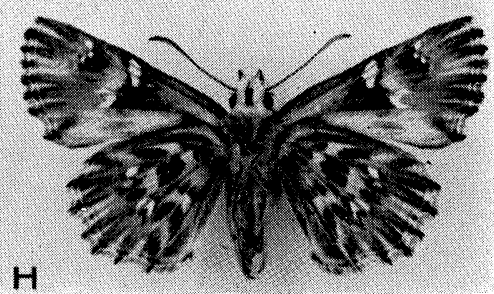

Fig. 1. Facies of Celotes.

C.nessus $\quad\left\{\begin{array}{llll}\mathrm{A} & \mathrm{B} & \rightarrow & \hat{0} \\ \mathrm{C} & \mathrm{D} & \rightarrow & + \\ \mathrm{E} & \mathrm{F} & \rightarrow & \hat{o} \\ \mathrm{G} & \mathrm{H} & \rightarrow & \stackrel{+}{\downarrow} \\ \text { dorsal } & \underset{\downarrow}{\downarrow} & & \end{array}\right.$


raise additional hell with these subtle color characters, but no matter: the genitalia (q.v.) last and last.

Male scent-spreading sex characters. - Males of limpia, like those of nessus, have a narrow costal fold on the primary and a metathoracic system of ventral pouch and tibial tufts. The metathoracic pouch of limpia (fig. $2 \mathrm{~B}$ ) bears short linear scales over most or all of its dorsal surface (except at the lateral margin). In nessus (fig. 2A), linear scales are altogether absent (particularly in Arizona males) or, if present (as in Texas males), are much less dense and/or proximal in distribution; even in extreme cases, they never attain the distal apex of the pouch, and the pouch is therefore clad -entirely or for its greater part - with much broader, flat-lying shinglelike scales (cf. figs. $2 \mathrm{~A}$ and $2 \mathrm{~B}$ ). Because the linear scales of limpia are creamy, whereas some to all of the broad shinglelike scales of nessus are gray to brown, the general color of the dorsal surface of the metathoracic pouch differs in the two species. (Interior morphology of costal folds has not been studied.)

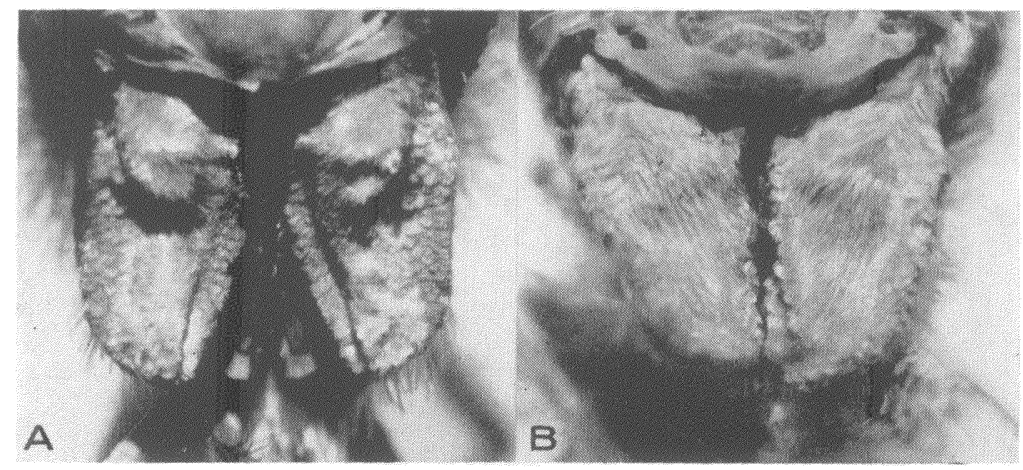

Fig. 2. Metathoracic pouch of the male; abdomen removed, dorsoposterior view. A. Celotes nessus from Austin, Travis County, Texas, V-261966 (J. M. Burns). B. Celotes limpia, a paratype reared out IX-10-1966 from a larva collected on Abutilon malacum, 15 mi. SE Redford, $2500 \mathrm{ft}$., Presidio County, Texas, VIII-18-1966 (R. O. Kendall).

Male genitalia. - Fig. 4. Although basically similar to nessus (fig. 3), there are abundant differences, of which the most salient include the following. ( I ) In limpia, a long thin flattened projection, like a curved spatula, arises from the dorsoposterior rim of the body of the valva and starts dorsad but at once curves caudad, extending far back to become the caudalmost valval element and to end in a 
slightly flared tip with a peripheral array of fine sharp teeth (fig. $4 \mathrm{~A}-\mathrm{C})$. Its homolog in nessus is a robust spike arising in a similar position, except that the distinctive high dorsal curvature of the body of the valva in nessus places the origin of the spike well down on the medial surface of the valva (fig. $3 \mathrm{~A}-\mathrm{C}$ ) ; this tapering spike extends chiefly dorsad, but usually bends slightly caudad at its apex, which is pointed and often entire or bifurcate (fig. $3 \mathrm{~A}, \mathrm{~B}$ ), but sometimes trifurcate, or very rarely quadrifurcate; although occasionally broadened or lengthened and bent strongly caudad apically, the spike never approaches the form of the spatula in limpia. (2) Anterior end of tegumen, in limpia, large and well-developed, projecting far cephalad (fig. $4 \mathrm{E}, \mathrm{F}$ ); but in nessus, extraordinarily reduced (fig. $3 \mathrm{E}, \mathrm{F}$ ). (3) In limpia, uncus broad, and the paired terminal prongs of the uncus heavy and stubby (fig. $4 \mathrm{~F}$ ); but in nessus, uncus relatively narrow, and its terminal prongs more delicate (fig. $3 \mathrm{~F}$ ).

Female genitalia. - Fig. 6. Sterigma of limpia altogether more massive (fig. 6A,B) and, viewed ventrally, more nearly square in outline (fig. 6A); heavy central sclerotization in lamella postvaginalis like a wide triangle tapering quickly toward ostium bursae (fig. 6A). Sterigma of nessus (fig. 5) less massive (fig. 5A,B) and, in ventral view, narrower posteriorly, suggesting in outline a caudally truncated triangle (fig. $5 \mathrm{~A}$ ) more than a square; heavy central sclerotization in lamella postvaginalis limited to a comparatively narrow midventral strip that tapers but little toward ostium bursae (fig. 5A). Ostium bursae of limpia a relatively narrow curved slit, like a crescent bowed dorsad (fig. 6C), but that of nessus large and more or less round, like a manhole (fig. $5 \mathrm{C}$ ).

Spatial distribution. - A widespread species, nessus ranges from about the 97th meridian in southcentral Oklahoma and central Texas west to northwestern and southeastern Arizona and south in Mexico to at least southern Sonora, southern Chihuahua and Coahuila (fig. 7). By contrast, so far as known, limpia occurs only along the southern Rocky Mountain axis in Trans-Pecos Texas and along the Mexican counterpart of this axis, the northern segment of the Sierra Madre Oriental, as far south at least as southern Coahuila (fig. 8). Having been taken in numbers in the Guadalupe, Davis, and Chisos mountains of Trans-Pecos Texas, limpia may confidently be expected (I) in many other west Texan ranges - such as the Delawares, Chinatis, and Santiagos - that are more or less associated with the scattered southern Rocky Mountain system, (2) northward in at least the New Mexican extension of the Guadalupes, if not in the Sacramentos and more northern chains, and (3) southward in Chi- 


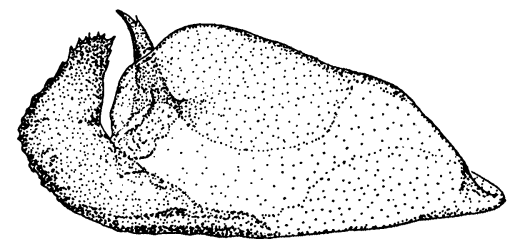

A

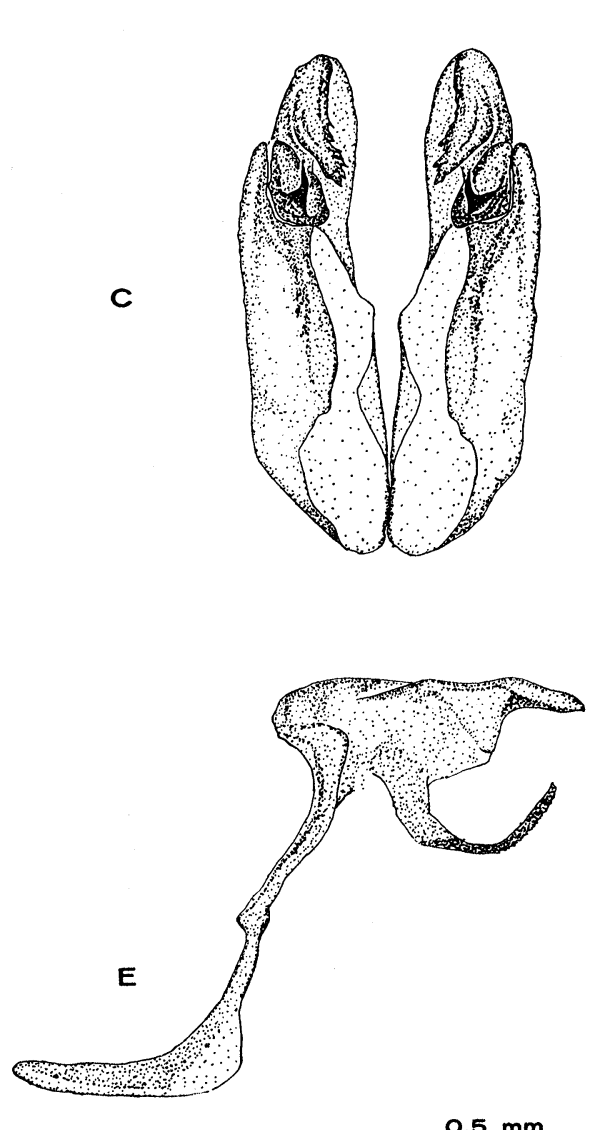

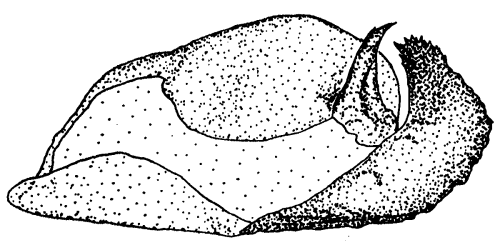

B

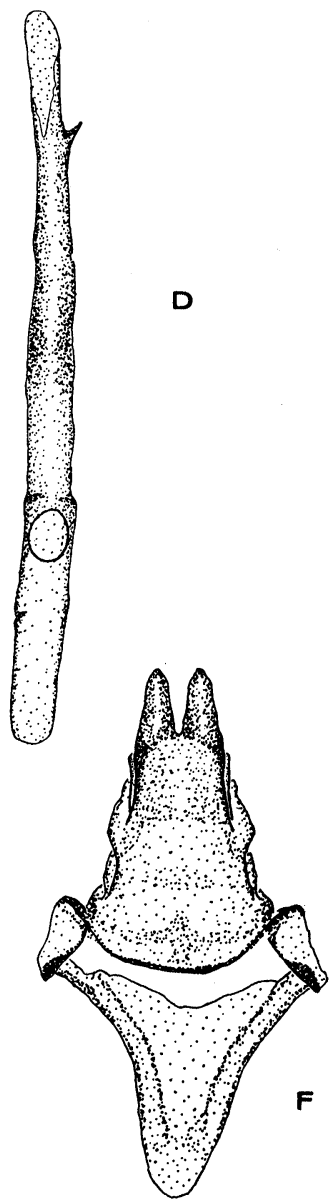

Fig. 3. Male genitalia of Celotes nessus. A. Lateral view of right valva. B. Medial view of right valva. C. Dorsal view of both valvae. D. Dorsal view of aedeagus. E. Left lateral view of uncus, tegumen, gnathos, vinculum, and saccus. F. Dorsal view of uncus, tegumen, vinculum, and saccus. [A and B, drawn from male from Palo Duro Canyon, 2800 feet, Randall County, Texas, V-10-1959 (J. M. and S. N. Burns) ; C to F, from male from Austin, Travis County, Texas, V-26-1966 (J. M. Burns).] 


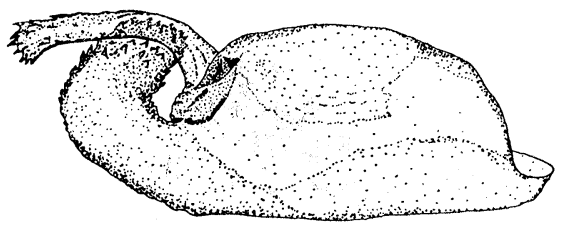

A

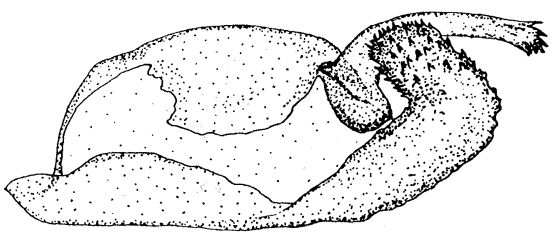

B
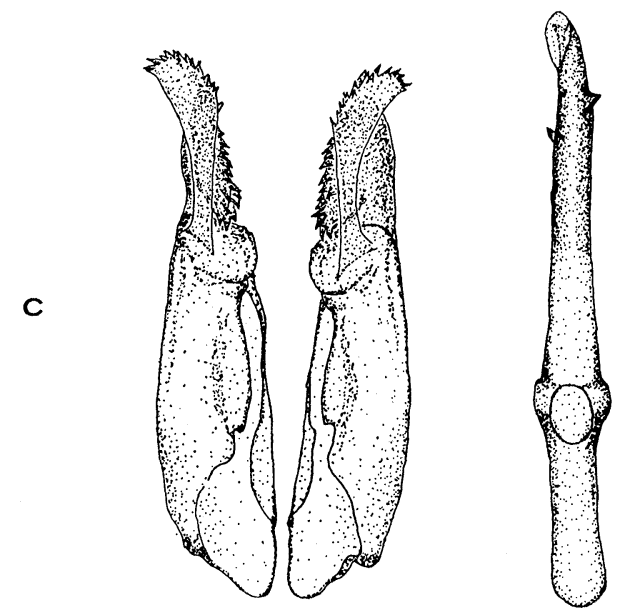

D
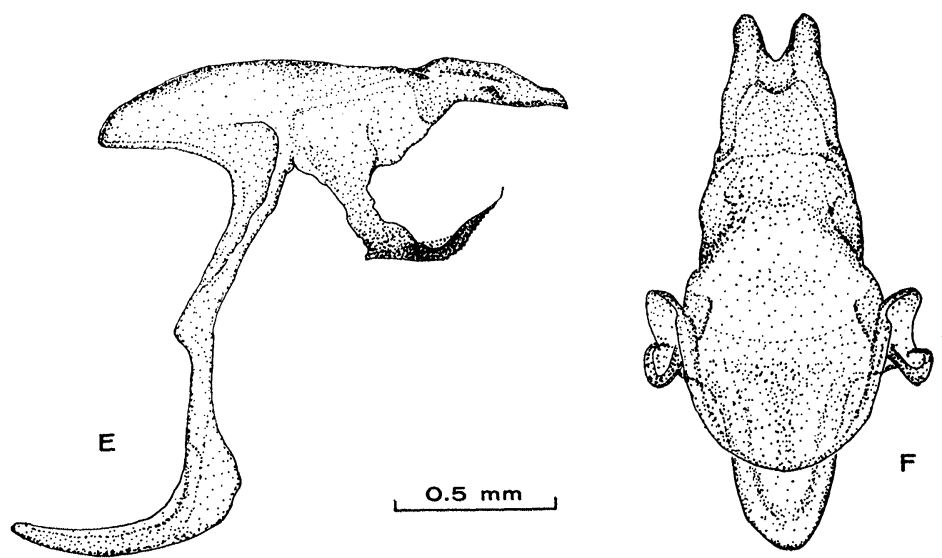

Fig. 4. Male genitalia of Celotes limpia. A to $\mathrm{F}$ as in fig. 3. [A and B, drawn from holotype; $C$ to $F$, from paratype from type locality, V-4-1959 (J. M. and S. N. Burns).] 

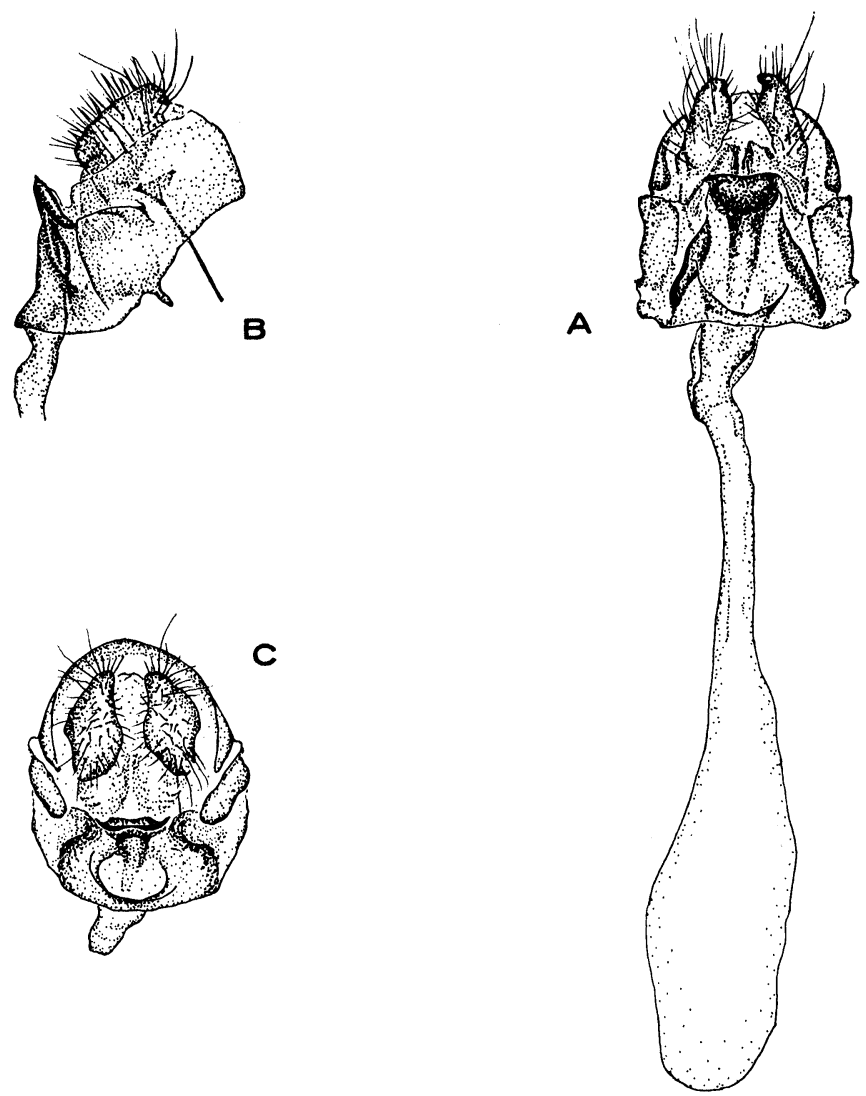

Fig. 5. Female genitalia of Celotes nessus. A. Ventral view of bursa
copulatrix, sterigma, and ovipositor lobes. B. Right lateral view. C. Vencopulatrix, sterigma, and ovipositor lobes. B. Right lateral view. C. Ven-
troposterior view. [Drawn from female from Austin, Travis County, Texas, IV-18-1967 (J. M. Burns).] 

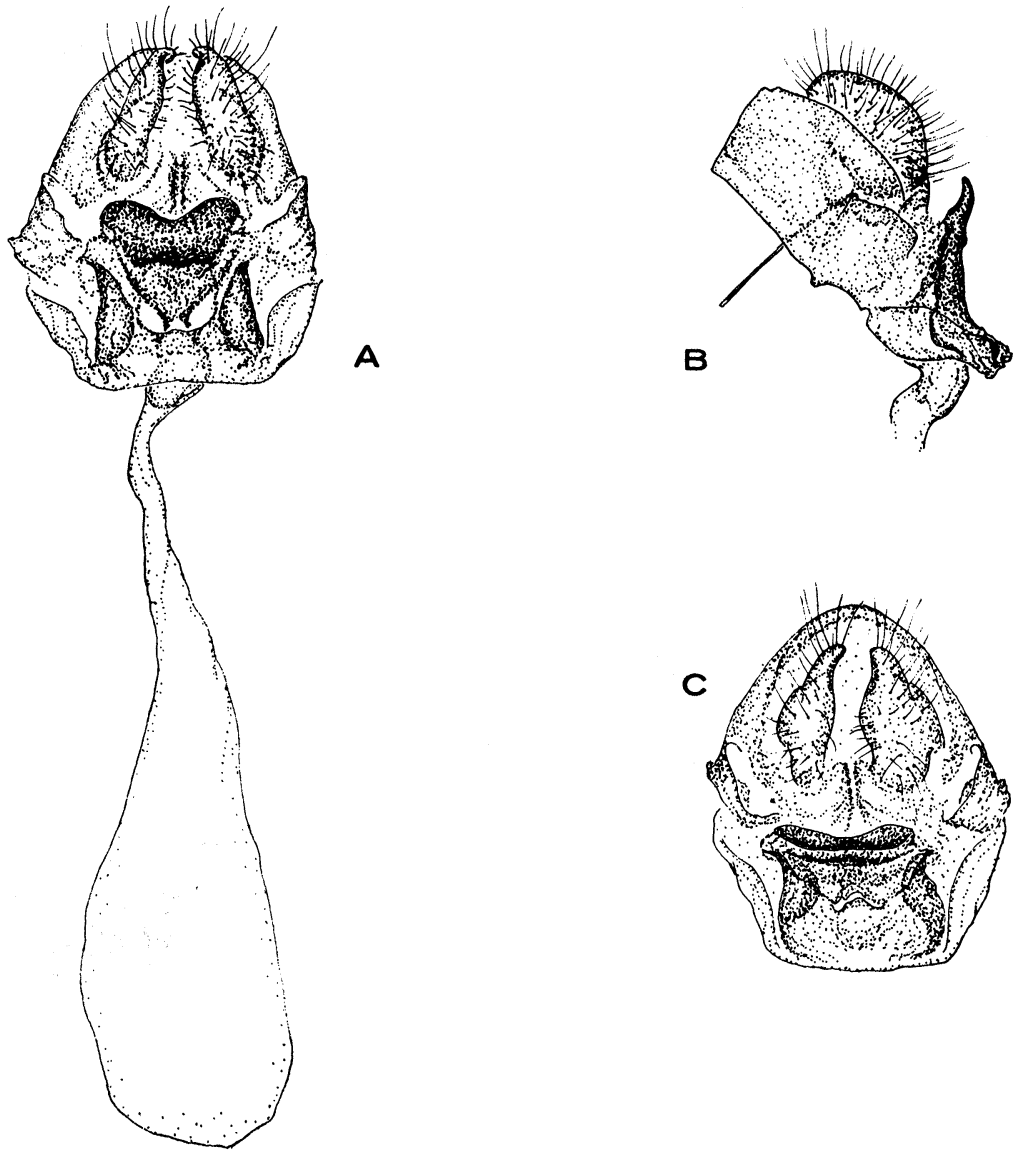

A

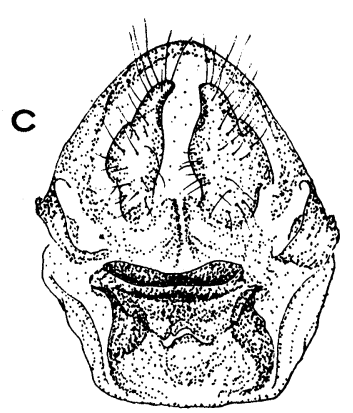

Fig. 6. Female genitalia of Celotes limpia. A. Ventral view of bursa copulatrix, sterigma, and ovipositor lobes. B. Left lateral view. C. Ventroposterior view. [Drawn from paratype from Limpia Canyon, 4700 feet, Davis Mountains, $5 \mathrm{mi}$. NE of Fort Davis, Jeff Davis County, Texas, V-41959 (J. M. and S. N. Burns).] 


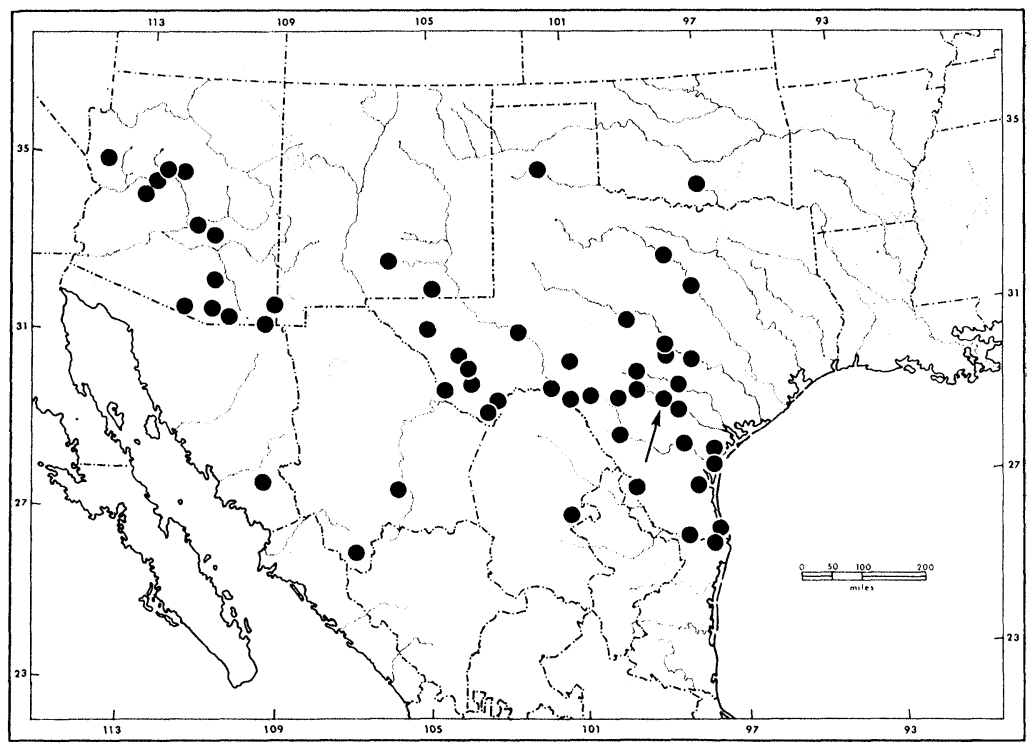

Fig. 7. Spatial distribution (based on material examined) of Celotes nessus - southwestern United States and northern Mexico. Rivers and the borders of states are shown. Type locality indicated by arrow.

huahua, as well as Coahuila, and, in all likelihood, beyond these states. Indeed, either limpia or nessus (see Nomenclatural epilogue below) was long ago reported from Durango city (Godman and Salvin I899), and both species probably range well down the Central Plateau of Mexico. The distribution of limpia appears to lie within that of nessus.

Over its much broader distribution, nessus occurs from sea level to somewhere between 5000 and 6000 feet; limpia, with its strictly interior distribution, is now known from an elevational range of 1900-5700 feet. In montane regions of the southwestern United States, both skippers are species of alluvial fans, foothills, lower canyon reaches, and lower elevations generally; they avoid higher elevations.

The distribution of nessus in the United States is not perfectly known. The skipper may conceivably occur in the New York and Providence mountain region of southeastern California, in southern Nevada, in southern Utah, possibly in extreme southwestern or southeastern Colorado, and certainly in considerably more of New Mexico 


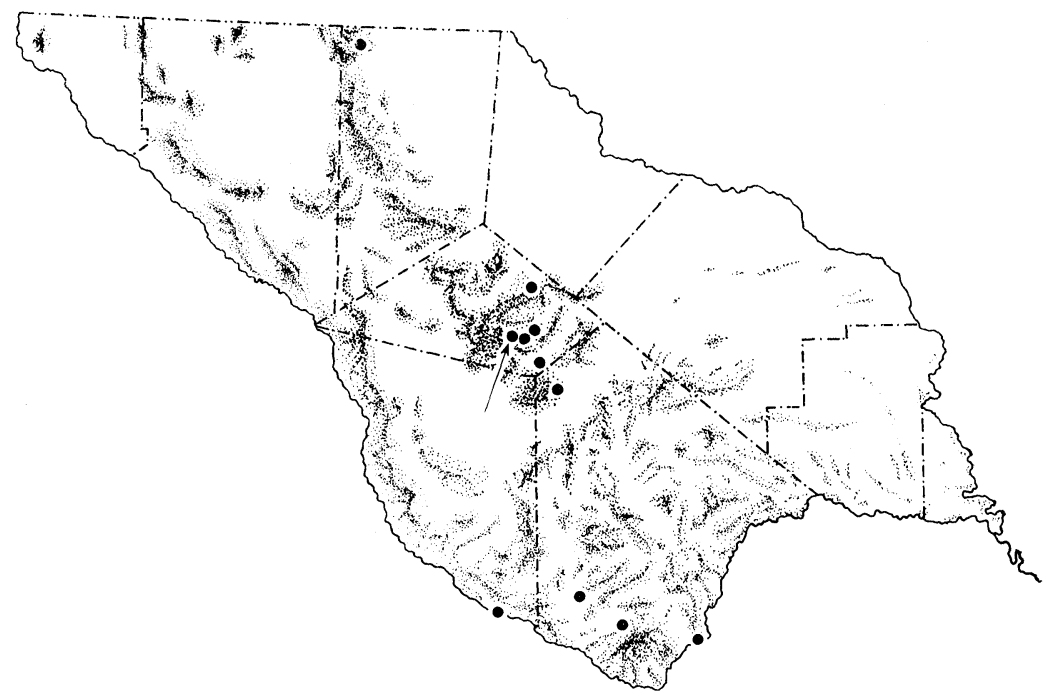

Fig. 8. Spatial distribution (based on material examined) of Celotes limpia - Trans-Pecos Texas. Mountains and the borders of counties are shown. Type locality indicated by arrow. The range as plotted spans a north-south distance of about 220 miles; but, since preparing this map, I have examined one male from southern Coahuila, Mexico, about 250 miles southeast of the Big Bend.

than fig. 7 indicates. On the other hand, this map probably gives a close approximation of the eastern distributional limit of nessus. This meridional eastern limit coincides neatly with that of many other organisms - including other pyrgine skippers of the southwestern United States and northern Mexico such as Pyrgus philetas Edwards (Burns and Kendall 1969) and Erynnis meridianus Bell (Burns I964, and unpublished) - and reflects an important biogeographic barrier.

There are two freaky records of streaky nessus east of the 97th meridian. The first [Burton, Georgia, V-2I-I9I I (J. C. Bradley) (Cornell University collection)] was published by Harris (1950) and repeated [as "Georgia (once!)"] by Klots (195I), but was not even mentioned later by Harris (1972) and should be discounted. The second [Tallulah, Louisiana, between VIII-I926 and X-193I (collected in the day at an altitude of 20 feet by an airplane)] was published by Glick (1939); but though it has been repeated (Lambremont 1954; Mather and Mather 1958), the feat itself has not. 
Temporal distribution. - Both limpia and nessus are multivoltine, and both fly at the same times. Nearly all of the dated wild-caught adults of Celotes that I examined were collected from March to September: in Texas, every half-month interval from the beginning of March to mid-September includes records of both limpia $(\mathrm{N}=68)$ and nessus ( $\mathrm{N}=\mathrm{I} 58)$; however, for Arizona nessus $(\mathrm{N}=\mathrm{I} 83$ ), the months of May and June together yield but 3 records, which leaves a major gap between one large cluster of records in March and April and another in July, August, and the first half of September. The only other dated wild-caught specimens examined are 5 nessus from far southern Arizona collected in mid-January and 5 nessus from the last half of September and the first half of October from central and, as might be expected, extreme southern Texas (the lower Rio Grande Valley). In the experience of Kendall (1965), nessus flies from early March to mid-November in Texas.

The fact that temporal distribution is essentially continuous through the warm season for both limpia and nessus in Texas but distinctly bimodal for nessus in Arizona probably relates to the different patterns of rainfall in the two states. For the most part, Texas has much more evenly distributed precipitation than does Arizona, where it occurs in two widely disjunct winter and summer periods. The second flight period of nessus in Arizona coincides with the summer rainy season, to which it is presumably geared. In the course of his field studies and laboratory rearings, Kendall (1965, and unpublished) has observed that full-grown larvae of Celotes are able to enter diapause (facultatively) to beat heat and drought, as well as to get through the cold of a winter season. Kendall has shown in the laboratory that such diapause can be broken by providing moisture, whereupon larvae pupate and produce adults promptly. Given this capacity to be flexible, variable larval growth rates, and the usual vicissitudes of weather, individuals of a single generation must often get out of synchrony with the result that generations overlap broadly and irregularly, forming no definite number per year in either species.

There are no indications that limpia and nessus are temporally displaced with respect to each other where they spatially coexist in Trans-Pecos Texas. Rather, my records show that adults of both species have repeatedly been collected in association - unwittingly, of course, since the collectors were unaware of the existence of more than one species of Celotes. On nine occasions altogether, five different collectors (or pairs of collectors) have caught a total of 37 
limpia and nessus at the same place on exactly the same date - the places occurring in Jeff Davis and Brewster counties and the dates in March, May, June, July, and August. Many other records of both species at a single locality differ by only one to a few days.

Larval foodplants. - Numerous studies in Texas by R. O. and C. A. Kendall show that both limpia and nessus feed on various species of Malvaceae. For both skippers, the Kendalls have witnessed oviposition - directly on larval foodplants - in the wild, and have collected numerous eggs and larvae from which they have reared adults.

In the field, limpia eats Abutilon malacum Wats., A. incanum (Link) Sweet, Sphaeralcea angustifolia var. lobata (Woot.) Kern., and Wissadula holosericea (Scheele) Gke., and, in the laboratory, also Malvastrum americanum (L.) Torr. and Althaea rosea Cav. In the field, nessus eats Abutilon incanum, Sphaeralcea angustifolia var. lobata, Wissadula holosericea, W. amplissima (L.) R. E. Fries, and Sida filipes Gray, and, in the laboratory, also Althaea rosea. Both skippers very likely eat other mallows, as well.

Documentation: Eggs and larvae of Celotes were found on Sphaeralcea angustifolia var. lobata at Davis Mountains State Park, Jeff Davis County, V-I-6r, by R. O. and C. A. Kendall. At the laboratory in San Antonio, those larvae that were not preserved were reared perforce on Althaea rosea. One adult was obtained from a larva on V-28-6I and two from eggs on VI-6 and 9-6r. Although all were reported as nessus (Kendall I965), I find that only the adult that emerged VI- 6 is nessus whereas those that emerged V-28 and VI-9 are limpia (paratypes).

From 3 larvae found by the Kendalls on Wissadula holosericea in Musquiz Canyon on state highway I I8, Jeff Davis County, VIIII4-66, I adult (a paratype of limpia) was obtained on IV-I 4-67.

From 2 larvae found by the Kendalls on Abutilon incanum near Rio Grande Village in Big Bend National Park, Brewster County, $\mathrm{X}-\mathrm{1} 2-67,2$ adults of limpia (paratypes) were obtained (after a lengthy diapause) on VI-I9 and 22-68. At the same locality, III27-68, the Kendalls saw a female of Celotes oviposit on $A$. incanum but got only the egg and not the female; from this egg, an adult of limpia (paratype) was obtained on V-29-68.

The Kendalls collected 23 larvae on Abutilon malacum, VIIII 8-66, at a point on ranch road I70 overlooking the Rio Grande, about 15 miles southeast of Redford, Presidio County; and, using A. incanum, Malvastrum americanum, and especially Wissadula 
holosericea as larval food in the laboratory, they reared 22 adults of limpia (all paratypes) (one seemingly parasitized larva was preserved). At exactly the same spot, X-I I-67, the Kendalls collected about 40 more Celotes larvae on $A$. malacum and reared 23 adults (apparently limpia, but none of them examined by me).

Foodplant records for nessus are legion (Kendall 1959, 1965, and unpublished). Most of them are of Abutilon incanum; and these come from many counties in central Texas: Bexar (innumerable records), Blanco, Bosque, Comal, Crockett, Kerr, Kimble, Llano, Maverick, McCulloch, Medina, Nueces, San Patricio, Travis, Uvalde, and Val Verde. I have examined much of the nessus material reared on $A$. incanum.

The one valid record of nessus found as an egg on Sphaeralcea angustifolia var. lobata in Jeff Davis County, Trans-Pecos Texas, and reared to an adult in the laboratory on Althaea rosea was discussed above; the other two adults reared from this lot of eggs and larvae on Sphaeralcea are actually limpia, though they, too, were reported (Kendall i 965 ) as nessus.

Three larvae found on Sida filipes in San Antonio, Bexar County, V-9-63, and kept on this plant, produced adults of nessus (not seen by me) on VI-8, I4, and VII-II-63 (Kendall 1965).

A larva found by the Kendalls on Wissadula holosericea in San Antonio, Bexar County, V-24-65, yielded an adult of nessus (seen by me) on VI-I I- 65 .

Three larvae found on $W$. amplissima in extreme southern Texas at the Laguna Atascosa National Wildlife Refuge, Cameron County, IV-2I-62, produced adults of nessus (all seen by me) on V-I 5, VI-4, and VIII-20-62 (Kendall I965).

Hypodigm. - Of limpia: the holotype $0^{x}$ specified earlier, an allotype + with identical data (except $\mathrm{V}-\mathrm{I}-59$ ), and paratypes comprising $640^{x} 30 \%$ from Trans-Pecos Texas and I $0^{x}$ from Mexico. Paratypic data arranged in the system described by Burns (1964: 19-20), with names of recurring collectors abbreviated: J. M. and S. N. Burns to B, H. A. Freeman to F, and R. O. and C. A. Kendall to K.

MEXICO. CoAhuila. 25 mi. N Saltillo, IX-ig-69, I ơ (J. A. Scott).

UNITED STATES. Texas. Brewster County: Alpine, V-2026, I $0^{\pi}$ (O. C. Poling) (MCZ); V-2I-26, I $0^{\pi}$ (O. C. Poling) (MCZ); VI-4-42, I $0^{\pi}(\mathrm{F})$; VI-5-42, I $0^{\pi}$ (F) ; VI-6-42, $30^{\pi}(\mathrm{F})$; VI-7-49, I $0^{\pi}(\mathrm{F})$; VII-IO-49, Iㅇ (F); VIII-9-52, $20^{\pi}(\mathrm{F})$; VII-28-53, I $0^{\pi}(\mathrm{F})$; VI-16-60, I우 (F); III-I 4-6I, I $0^{\pi}$ (W. S. 
McAlpine); III-27-6I, $70^{\pi}$ (W. S. McAlpine) (2 in PMY); VI-5-6I, I $\sigma^{\top}$ (F). 8 mi. N Study Butte, 3500 ft., VII-I 5-63, I $\sigma^{*}$ (H. Clench) (CM). Big Bend National Park: The Basin, $5500 \mathrm{ft}$., IV-30-65, Iㅇ (K) ; IX-8-65, I $0^{\pi}(\mathrm{K})$. Oak Spring, $5700 \mathrm{ft}$, IX-9-65, Iq (K). Rio Grande Village, I900 ft., III-27-68, $30^{\text {* }}$ $(\mathrm{K})$; V-29-68, I $0^{\pi}$ reared from egg (K); VI-I9, 22-68, $20^{\star}$ reared from larvae $(\mathrm{K})$. Window, $5500 \mathrm{ft}$., VIII-I6-66, $30^{\star}(\mathrm{K})$. Culberson County: 2 mi. N Pine Springs, $5700 \mathrm{ft}$. , Guadalupe Mts., VII-19-63, $60^{7}$ (H. Clench) (CM). Jeff Davis County: I I mi. N Alpine, VI-20-68, $50^{\star}$ (J. A. Scott). I $3 \mathrm{mi}$. NW Alpine on state highway I I8, IV-17-60, I $0^{*}$ I 9 (K. Roever). Big Aguja Canyon, IV-2-68, $50^{\pi}(\mathrm{K})$. Davis Mts. State Park, V-28-6r, I $0^{\pi}$ reared from larva $(\mathrm{K})$; VI-9-6I, I우 reared from egg $(\mathrm{K})$. Ft. Davis, VIII-27-54, I $0^{7}$ (R. M. Bohart). Limpia Canyon, 4800 ft., Davis Mts., I mi. N Ft. Davis, IV-28-59, I $0^{\star}$ (B) (MCZ). Limpia Canyon, 5000 ft., Davis Mts., 4 mi. WNW Ft. Davis, IV-28-59, 2 우 (B) (MCZ); V-I-59, $20^{7}$ I우 (B) (MCZ); V-2-59, 2 우 (B) (MCZ) ; V-4-59, I $0^{\pi}$ (B) (MCZ). Limpia Canyon, $4700 \mathrm{ft}$., Davis Mts., 5 mi. NE Ft. Davis, V-4-59, I $0^{7}$ I 9 (B) (MCZ). Musquiz Canyon on state highway II 8, VIII-I4-66, $20^{\pi}(\mathrm{K})$; IV-14-67, Iㅇ reared from larva (K). Presidio County: $30 \mathrm{mi}$. SE Presidio along Rio Grande, III-26-66, 2 우 (D. J. Lennox). I5 mi. SE Redford on ranch road I70, $2500 \mathrm{ft}$., VIII-29, 30, 3I-66 and IX-I, 4, 5, 6, 7, 8, 9, IO, II, I 7, 29-66, $70^{7}$ I5ㅇ reared from larvae $(\mathrm{K})$.

Hypodigm of nessus summarized in table 2.

Table 2. Specimens of Celotes nessus examined.

\begin{tabular}{lrrr}
\hline $\begin{array}{l}\text { COUNTRY } \\
\text { State }\end{array}$ & $\hat{8}$ & $\%$ & $\mathrm{~N}$ \\
\hline $\begin{array}{l}\text { MEXICO } \\
\text { Chihuahua }\end{array}$ & 3 & 1 & 4 \\
Coahuila & & 2 & 2 \\
$\quad$ Sonora & 7 & & 7 \\
UNITED STATES & & 24 & \\
$\quad$ Arizona & 169 & 2 & 193 \\
New Mexico & 8 & 1 & 10 \\
Oklahoma & 1 & 67 & 2 \\
Texas & 147 & 97 & 432 \\
\hline & $\mathrm{N}=335$ & &
\end{tabular}


Nomenclatural epilogue. - A species of what we now call Celotes was named three times within less than a decade, I 877 to 1884 (see e.g. Lindsey, Bell and Williams 1931; Evans 1953). In order of publication, the names are Pholisora nessus Edwards, Spilothyrus notabilis Strecker, and Carcharodus radiatus Plötz. The fact that I have made no effort to examine types is not so cavalier as it might seem. On the one hand, genus Celotes is such a distinctive element of the American fauna that one may safely assume that all three names have long since been assigned to it correctly. On the other hand, one may also assume that all three refer to nessus rather than to limpia for the following reasons. The type locality for both nessus and notabilis is San Antonio (or perhaps the nearby town of New Braunfels for the latter), at the eastern edge of the main range of nessus and therefore a few hundred miles removed from the nearest populations of limpia in Trans-Pecos Texas. Because intervening areas have now been well-collected, the total lack of limpia from eastcentral Texas is real. The type locality for radiatus is simply Texas; but, inasmuch as the name was published in 1884 , the material on which it was based almost certainly came from central Texas, too. The west Texas areas in which limpia occurs are relatively remote. Indeed, in all of the material assembled from museums for this study, there were only two specimens of limpia that had been collected prior to $196 \mathrm{I}$ - and they were taken in 1926 .

Godman and Salvin ( 1899) proposed Celotes as a monotypic genus with Pholisora nessus Edwards as its type-species. There is some historical and distributional interest in noting that their hypodigm of "nessus" undoubtedly included nessus but may have been mixed. As they themselves said, it comprised 3 specimens from Texas provided by Strecker and 3 from Mexico (Northern Sonora and Durango city). Strecker's notabilis (=nessus) was one of a series of lepidopterans that he described from material collected "by Mr. J. Boll, mostly in the vicinity of New Braunfels and San Antonia [sic]" (Strecker 1878). Owing to its geographic origin, the Strecker material certainly - and that from Northern Sonora almost certainly - would have been nessus. Furthermore, the male genitalia that Godman and Salvin clearly figured (pl. 91, fig. 29) belong without question to nessus. The Durango material is problematic, however. To judge from the locality, it might almost as well be limpia as nessus. Godman and Salvin's color illustrations of dorsal and ventral aspects of a female of Celotes (pl. 9I, figs. 27, 28) could be taken for either species, the dorsal view (fig. 27), in particular, being 
rather more reminiscent of limpia with respect to both facies and size. Unfortunately, the geographic source(s) of the female(s) on which these figures are based was not indicated, but probability favors Mexico: Evans (1953) records that the holdings of the British Museum by then included Io specimens of nessus from Texas, of which just 2 are females, but still only 3 from Mexico, to wit, "I $0^{7}$ 2 ?" from "N. Sonora. Durango." I would not be surprised to find that Godman and Salvin depicted a female of limpia from Durango.

\section{SUMMARY}

Celotes limpia, a new species of skipper butterfly in a hitherto monotypic genus, is described and extensively compared with $C$. nessus, which it closely resembles in superficial appearance and biology. Of 529 specimens examined, 97 represent the new species. Whereas C. nessus ranges widely (from central Texas and Oklahoma west to northwestern Arizona and south to at least the northern tier of Mexican states), C. limpia is relatively restricted, occurring within the range of $C$. nessus in Trans-Pecos Texas and interior northern Mexico. In Trans-Pecos Texas, where the only direct comparisons could be made, the two species are not only sympatric but also synchronic, flying in an indefinite number of generations from March to September. Larvae of both skippers are known, in the field, to eat various plants in the Malvaceae: Abutilon incanum, A. malacum (limpia only), Wissadula holosericea, W. amplissima (nessus only), Sphaeralcea angustifolia var. lobata, and Sida filipes (nessus only). In the laboratory, additional malvaceous foodplants are Althaea rosea and Malvastrum americanum (limpia only). Celotes limpia and C. nessus differ slightly in size and strikingly in genitalic morphology (both male and female) and in the morphology of certain scales on a male secondary sex character having a presumed communicative function.

\section{Acknowledgements}

Thank you: for lending specimens, J. A. G. Rehn and D. C. Rentz and Academy of Natural Sciences of Philadelphia, F. H. Rindge and American Museum of Natural History, C. D. MacNeill and P. H. Arnaud, Jr. and California Academy of Sciences, J. A. Powell and California Insect Survey, H. K. Clench and Carnegie Museum, L. M. Martin and J. P. Donahue and Los Angeles County Museum of Natural History, J. F. G. Clarke and W. D. Field and 
National Museum of Natural History, C. L. Remington and Peabody Museum of Yale University, F. H. Chermock, H. A. Freeman, R. O. Kendall, D. J. Lennox, C. D. MacNeill, B. Mather, D. Patterson, K. Roever, and J. A. Scott; for discovering foodplants, R. O. and C. A. Kendall ; for drawing genitalia, R. G. Gillmor; for photographing adults, T. P. Webster; for photographing metathoracic pouches, F. White; and for providing financial support, National Science Foundation grants GB-5935 and GB-37832.

Burns, J. M.

\section{Literature Cited}

1964. Evolution in skipper butterflies of the genus Erynnis. Univ. California Publ. Entomol. 37 : 216 pp., 1 pl.

Burns, J. M. And R. O. Kendall

1969. Ecologic and spatial distribution of Pyrgus oileus and Pyrgus philetas (Lepidoptera: Hesperiidae) at their northern distribu-

EDWARDs, W. H. tional limits. Psyche 76: 41-53.

1877. Descriptions of new species of butterflies belonging to the $\mathrm{N}$. American fauna. Canad. Entomol. 9: 189-192.

Evans, W. H.

1953. A catalogue of the American Hesperiidae indicating the classification and nomenclature adopted in the British Museum (Natural History). Part III. Pyrginae. Sec. 2. London: British Museum. 246 pp., pls. 26-53.

Glick, P. A.

1939. The distribution of insects, spiders, and mites in the air. U. S. Dept. Agr., Tech. Bull. no. 673. 150 pp.

GodMan, F. D. AND O. SALVIN

1879-1901. Biologia Centrali-Americana. Insecta. Lepidoptera-Rhopalocera. Vol. 2, 782 pp.; vol. 3, 113 pls.

HARRIS, L., JR.

[1950]. The butterflies of Georgia (revised). Georgia Soc. Nat., Bull. no. 5 . vii $+33 \mathrm{pp}$.

1972. Butterflies of Georgia. Norman: Univ. Oklahoma Press. xxii + $326 \mathrm{pp}$.

Kendall, R. O.

1959. More larval foodplants from Texas. J. Lepidopterists' Soc. 13: 221-228.

1965. Larval food plants and distribution notes for twenty-four Texas Hesperiidae. J. Lepidopterists' Soc. 19: 1-33.

KLots, A. B.

1951. A field guide to the butterflies of North America, east of the Great Plains. Boston: Houghton Mifflin Co. xvi +349 pp., 40 pls. LAMBREMONT, E. N.

1954. The butterflies and skippers of Louisiana. Tulane Stud. Zool. 1: 125-164. 
Lindsey, A. W., E. L. Bell and R. C. Williams, JR.

1931. The Hesperioidea of North America. Denison Univ. Bull., J. Sci. Lab. 26 : 1-142.

Mather, B. And K. Mather

1958. The butterflies of Mississippi. Tulane Stud. Zool. 6: 63-109.

STRECKER, H.

[1878] "1877." Lepidoptera, Rhopaloceres and Heteroceres, indigenous and exotic; with descriptions and colored illustrations. No. 14. Pp. 125-143. 

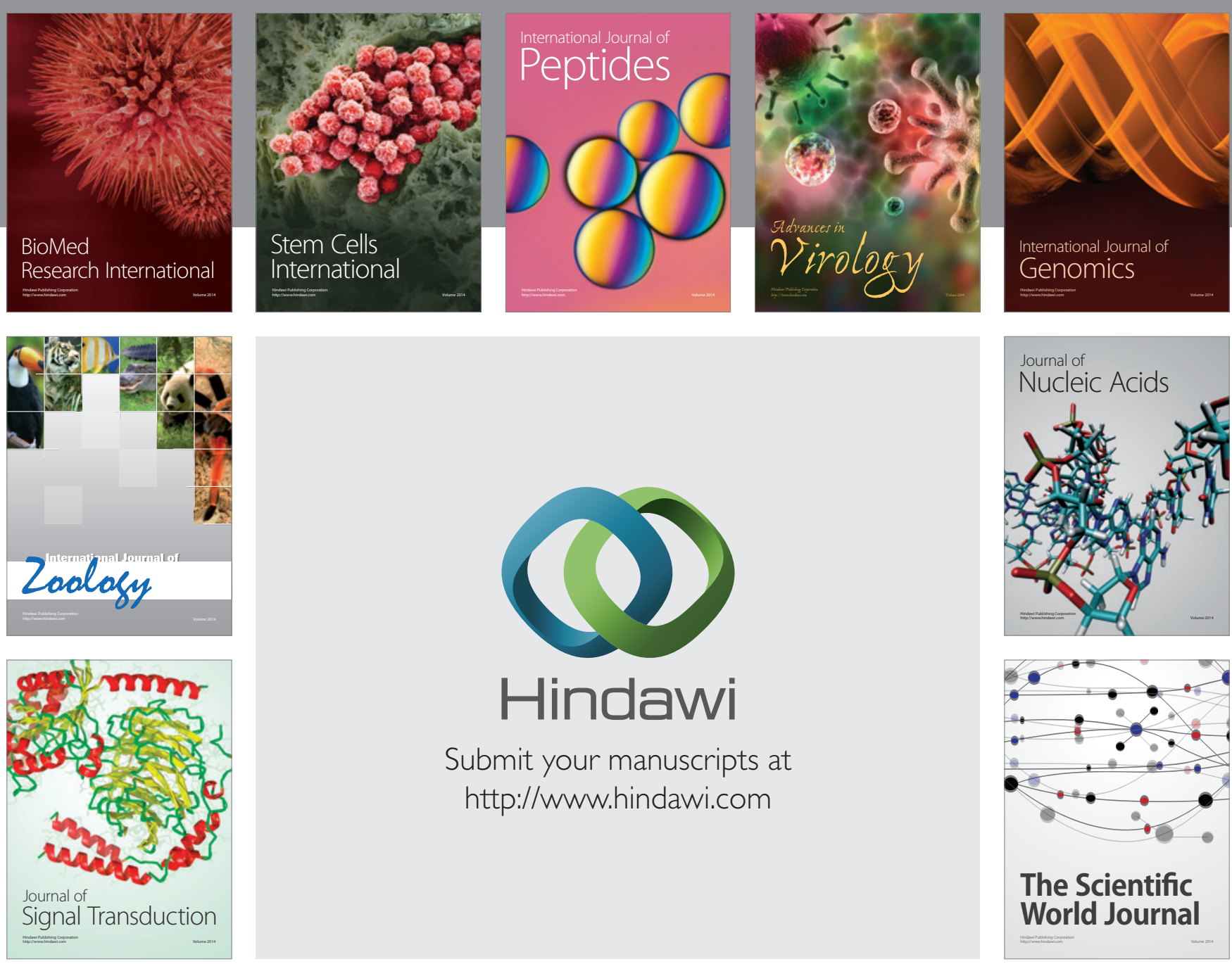

Submit your manuscripts at

http://www.hindawi.com
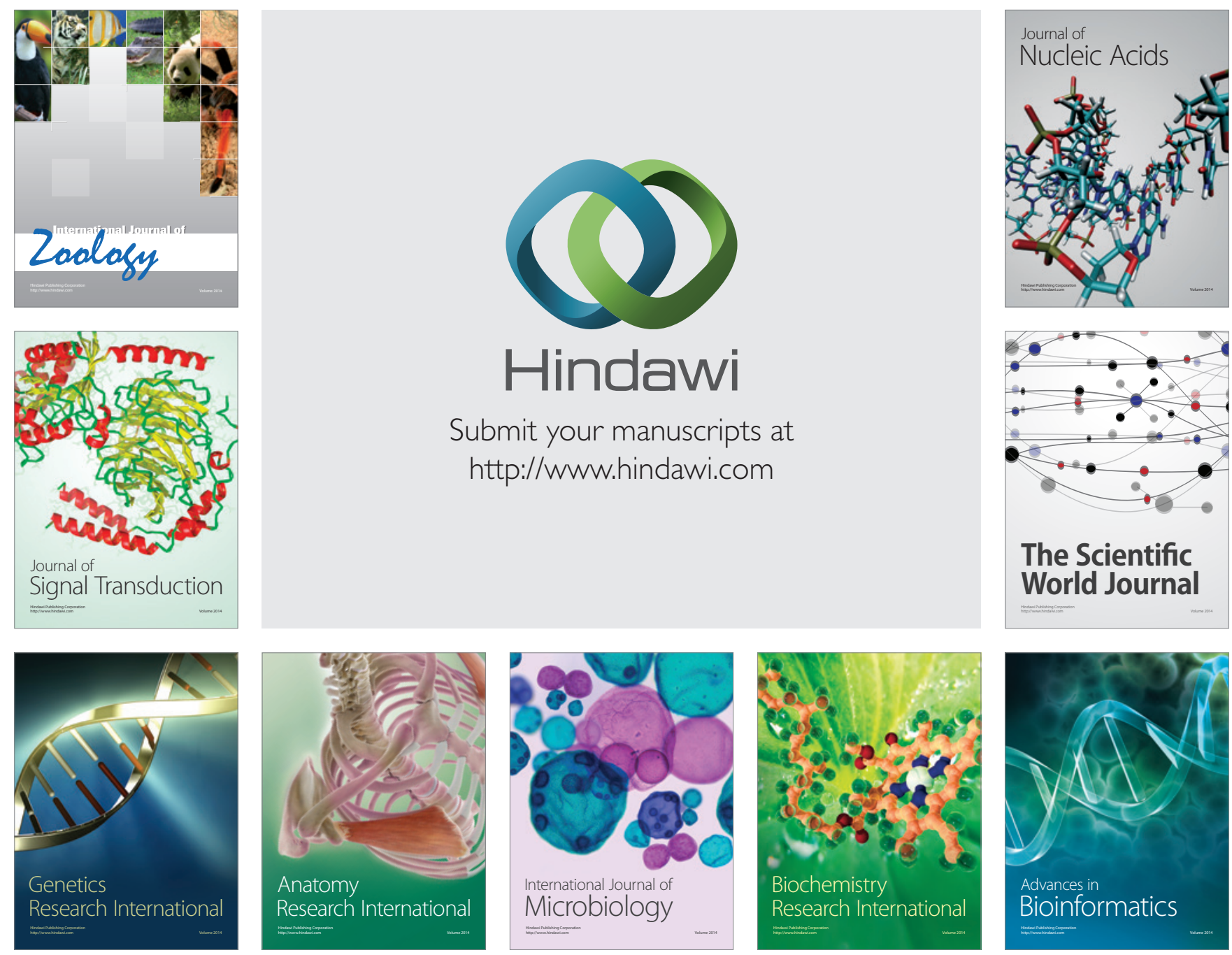

The Scientific World Journal
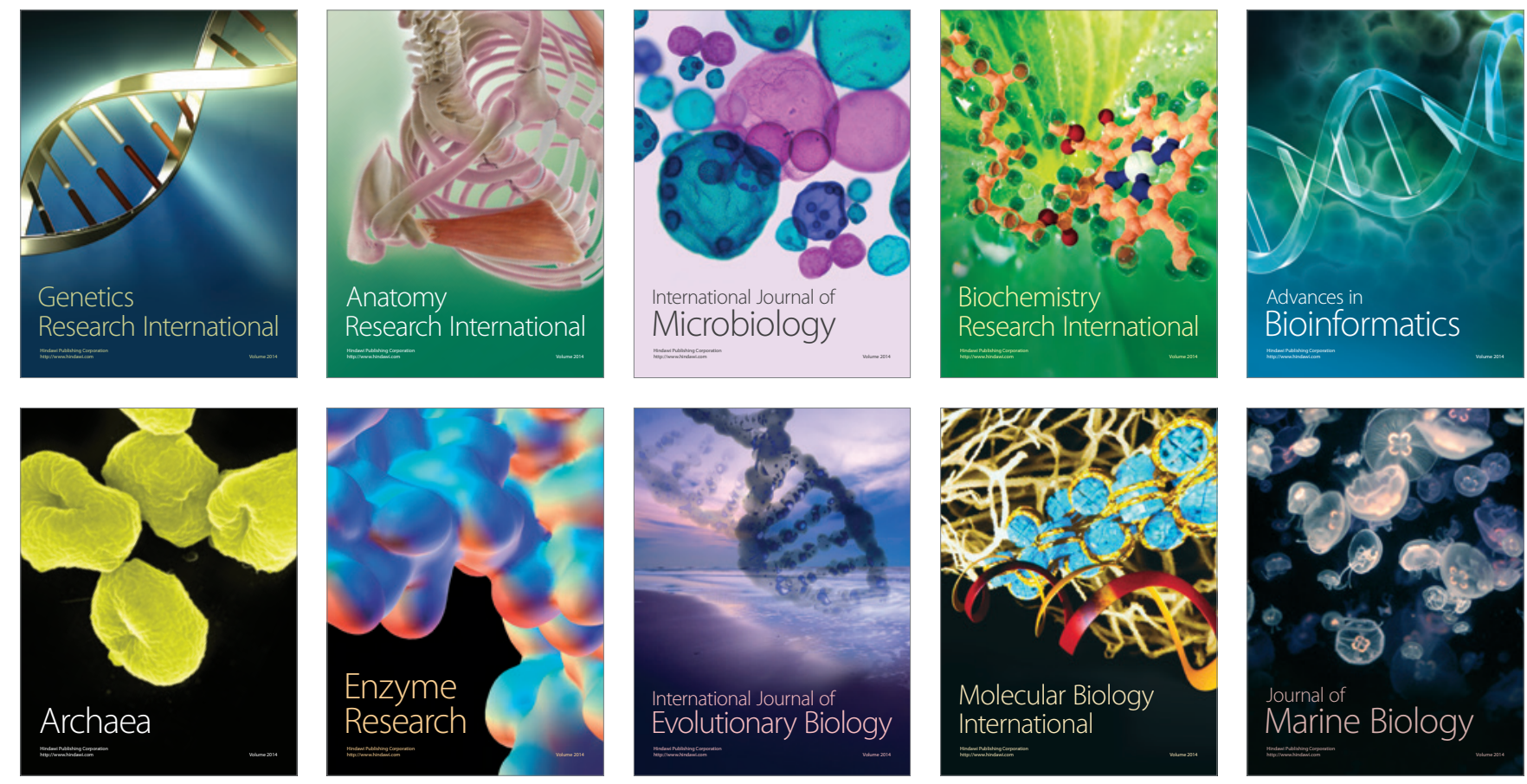